\title{
Development and life cycle analysis of double slope active solar still with flat plate collector
}

\author{
A.K. Sethi ${ }^{1^{*}}$ and V. K. Dwivedi ${ }^{2}$ \\ ${ }^{I^{*}}$ Research Scholar, Bhagwant University, Rajasthan, India \\ ${ }^{2}$ Deparment of Mechanical Engineering, Galgotias College of Engineering and Technology, Greater Noida, U.P, India
}

Received 15 October 2013; Accepted 3 February 2014

\begin{abstract}
Potable water is an essential ingredient of socio-economic development and economic growth. Often water sources are brackish (i.e. contain dissolved salts) and/or contain harmful bacteria and therefore cannot be used for drinking. In addition, there are many coastal locations where seawater is abundant but potable water is not available. This study is focused on a development of solar still with flat plat collector for water desalination considered for small scale applications at remote locations where only saline water is available. In this paper the cost of distilled water per $\mathrm{kg}$ has been calculated by using the concept of life cycle cost analysis. The pay back periods for different conditions of the distribution of distilled water, namely at the cost it is produced and at the selling price on market rate have been evaluated. The cost of water per kg is minimum Rs. 0.59 , when the interest rate and the lifetime of solar still are taken as $4 \%$ and 50 years respectively. The lowest payback time 1.23 years is obtained when the selling price of water Rs. 10 per $\mathrm{kg}$.
\end{abstract}

Keywords: Distill water, Life cycle, Payback period, Renewable Energy, Solar still

\section{Introduction}

The solution for supply potable water to the societies is to treat brackish water and remove impurities like salts, heavy metals and micro-organism. The conventional techniques for desalting water can broadly be classified into thermal and membrane based categories [1]. The former class of techniques includes multi-stage flash (MSF), multi-effect distillation (MED) and vapor compression distillation (VCD) while the latter class comprises reverse osmosis (RO), nano filtration (NF) and electro dialysis (ED). However, these techniques require a large input of energy and are not cost effective for low demands of clean water [2]. In thermal desalination, salts are removed from water by evaporation-condensation processes. Using solar energy for distillation is environmental friendly and available free of cost. A solar powered distillation device will contain three basic components: a basin in which the contaminated water is contained, a surface above said feed water for the water vapor to condense onto (i.e. a glass pane), and a channel for the distilled water to drain into. During operation of the distiller, solar energy is collected by the feed water through glass cover. When enough energy is absorbed by the water, the water undergoes a phase change. The water vapors then rises and comes into contact with the cooler transparent glass cover, inclined surface. Here the vapor once again goes through a phase change from vapor back to liquid. The water then condenses and runs off the transparent inclined surface

\footnotetext{
*E-mail address: anil_sethil@yahoo.com

ISSN: 1791-2377 @ 2014 Kavala Institute of Technology. All rights reserved.
}

into a collection channel. Any contaminants contained in the original feed water (such as salt, silt, and heavy metals) will remain in the distiller basin. The collected water vapor is now free of all prior contaminants and is fit for consumption.

In the last three decades, many new passive and active solar stills are developed all over world, and research works are still going on to improve the system performance and other aspects of solar stills. Sodha et al. showed that doublebasin type produced about a $56 \%$ higher yield than the single effect still by recovery / recycle of the latent heat of condensation within the solar still [3]. Zaki et al. was studied an active system of conventional single-slope solar still integrated with a flat plate collector under thermosyphon mode of operation and found that the maximum increase in the yield was up to $33 \%$ when the water in the still was preheated in the collector [4]. Tiwari and Yadav has been presented an economic analysis of the multi-wick solar distillation plant by taking into account the various factors, viz. the lifetime of the system, salvage values of the system, interest rate and maintenance cost [5]. Elsayed numerically compared single-effect diffusion still with a basin-type still and showed that the use of the diffusion-type still leads to an improvement in both production rate and operational efficiency [6]. Kudish and Gale had presented the cost analysis of solar distillation plant in Israel [7]. Mukherjee and Tiwari carried out cost analysis of three types of solar stills, viz. a single-slope fiber-reinforced plastic solar still, a double-slope fiber-reinforced plastic solar still and a doubleslope concrete solar still and found that the cost of distilled water produced from conventional double slope solar stills is minimum [8]. Delyannis presented the status of the solar 
assisted desalination that were installed in commercial and semi-commercial plants during that time [9]. Sinha et al. evaluated a collector assisted solar distillation system as an investment alternative to a solar hot water system. A technoeconomic analysis was performed for both systems in the same economic environment and considering the same capacity. It was concluded that the cost of energy from the distillation system is much less than the cost of energy obtained from the water heater, and the annual operation cost of the solar water heater is higher than that of the solar still because of the higher initial investment in the former [10]. Minasian and Al-Karaghoul connected a conventional basin type still (installed in a shadow and having an opaque cover) with a wick-type solar still so that the hot waste brine water leaving the wick-type feeds directly into the basintype, with the basin still cover cooled. The combined stills showed higher efficiency than the two stills separately, and the yearly amount of distilled water was $85 \%$ more than the basin type and $43 \%$ more than the wick type [11]. Kumar and Sinha concluded in their study that the yield of the concentrator-assisted solar still is much higher than any other passive/active solar distillation system [12]. Mu"llerHolst et al. presented a total life cycle cost analysis for this system under different modes of operation [13]. Lawrence et al. indicated that there is a significant effect of dye on still performance particularly for large water depth, and concluded that black dye gives a better performance than violet and red dyes [14]. Techno-economic analysis of multi-stage stacked tray solar still coupled with a solar collector was done by Adhikari et al. [15]. Thermoeconomic analysis of a solar multi-effect distillation plant installed at the Plataforma Solar de Almeria (Spain) was studied by García-Rodríguez and Gómez-Camacho [16]. Rubio-Cerda et al. studied Performance of the condensing covers under two still-orientations, east-west and northsouth. Their results showed larger differences in the condensers' temperatures and higher productivity when the still covers were facing east- west [17].Thermal-economic analysis of pyramid-shaped and single slope solar still configurations was done by Fath et al. [18]. Badran et a1. developed single slope solar still with reflecting mirrors fixed on interior sides was coupled with a flat plate collector. He found that the daily productivity increased $36 \%$ more than normal still operation due to coupling with solar collector. He also observed that increased in basin water depth decreases the productivity and still productivity was proportional to the solar radiation intensity [19]. Tiwari and Tiwari have carried out techno economic analysis of a single slope passive solar still based on annual performance [20]. M.K.Phadatare et al. studied the influence of water depth on internal heat and mass transfer in a plastic solar still and found that maximum distillate output of 2.1 $\mathrm{L} / \mathrm{m} 2 /$ day, at water depth of $0.02 \mathrm{~m}$ in still basin, could be achieved [21]. Ahsan and Fukuhara proposed a new mass and heat transfer model of a tubular solar still incorporating various mass and heat transfer coefficient taking account of the humid air properties inside the still [22]. Rajamanickam and Ragupathy study the effects of orientation and depth of water in the basin of the still on the productivity of a double slope solar still and compare the same with that of a single slope solar still [23]. Kabeel et al. found that stepped basin in the solar still improve the performance of solar still [24]. Tenthani et al. concluded that painting the internal surfaces of the walls of the still improves the distillate output of the still [25].
The objective of this work is to evaluate the cost of distilled water per $\mathrm{kg}$ and payback time by using the concept of life cycle cost analysis.

\section{System description}

Fig. 1 shows the schematic representation of an active solar still with a simple basin double slope cover. The overall dimensions of the still are shown in table 1.

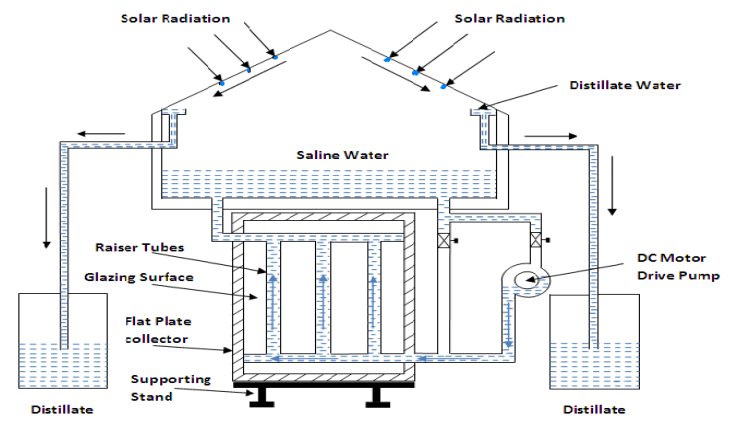

Fig.1. Schematic diagram of double slope active solar still

Table 1 Dimensions of double slope active solar still

\begin{tabular}{c|c}
\hline Parameters & Double slope \\
\hline Area of basin, $\mathrm{A}_{\mathrm{b}}$ & $2.0 \mathrm{~m}^{2}$ \\
Height of basin, $\mathrm{H}$ & $0.20 \mathrm{~m}$, at sides \\
$0.66 \mathrm{~m}$, at center \\
Area of condensing cover, $\mathrm{A}_{\mathrm{c}}$ & $1 \times 2 \mathrm{~m}^{2}$ \\
Thickness of condensing cover, $\mathrm{d}_{\mathrm{c}}$ & $0.004 \mathrm{~m}$ \\
Angle of condensing cover, $\theta_{\mathrm{c}}$ & $25^{\circ}$ \\
Thickness of insulation, $\mathrm{d}_{\mathrm{in}}$ & $0.006 \mathrm{~m}$ \\
\hline
\end{tabular}

Flat-plate collector is a metal box with a glass cover (called glazing) on top and a black-colored absorber plate on the bottom. The sides and bottom of the collector are insulated to minimize heat loss. The casing of collector plate surrounds the various components and keeps it free from dust and external environments. This experimental setup was designed, installed and tested in Galgotias College of Engineering \& Technology Greater Noida, India. The experimental setup was kept in the east-west orientation.

Thermocouple consists of copper $(100 \% \mathrm{Cu})$ and constantan $(55 \% \mathrm{Cu}+45 \% \mathrm{Ni})$ was used for temperature measurement. These thermocouples were fixed at still basin plate, water, inside and outside surface of the glass cover. Thermocouples were integrated with a temperature indicator and selector switch. The solar intensity was measured with the help of a calibrated solarimeter, having least count of 2 $\mathrm{mW} / \mathrm{cm}^{2}\left(20 \mathrm{~W} / \mathrm{m}^{2}\right)$. The experiments were conducted throughout a year starting from July 2011 to June 2012 and carried out from 9 a.m. and lasted for $24 \mathrm{hr}$. The solar radiation on solar still and collector plate, ambient temperature, the temperature of basin plate, saline water, glass cover inside and distilled water output are measured at an interval of $1 \mathrm{hr}$. 


\section{Economic Analysis}

3.1 Annual cost of the active solar distillation system

If $\mathrm{F}_{\mathrm{CR}, \mathrm{i}, \mathrm{n}}$, and $\mathrm{F}_{\mathrm{SR}, \mathrm{i}, \mathrm{n}}$, represent the capital recovery factor and sinking fund factor respectively, then for a given initial investment, the uniform end of year annual cost of the active solar distillation system can be written as follows, [26].

$U A_{n e t}=P_{S} \times F_{C R, i, n}+P_{S} \times F_{C R, i, n} \times M_{S}-S_{S} \times F_{S R, i, n^{\prime}}$

where, $F_{C R \text {, i,n }}$ and $F_{\mathrm{SR}, \mathrm{in},}$, can be calculated by using the following formula

$F_{C R, i, n \prime}=\frac{i(1+i)^{n \prime}}{(1+i)^{n \prime}-1}$

$F_{S R, i, n^{\prime}}=\frac{i}{(1+i)^{n \prime}-1}$

The cost of distilled water per $\mathrm{kg}$ based on thermal energy can be calculated by dividing the annual cost of the system by annual yield of solar still.

$C P L=\frac{U A_{\text {net }}}{M_{\text {yen }}}$

\subsubsection{Capital Cost of solar still $\left(\mathbf{P}_{\mathrm{S}}\right)$}

The capital cost of solar distillation system depends upon the size, design and materials of solar distillation system. The initial capital cost of solar still made of fibre reinforced plastic (FRP) can be expressed as follows:

$\mathrm{P}_{\mathrm{S}}=\mathrm{P}_{\mathrm{FRP}}+\mathrm{P}_{\mathrm{G}}+\mathrm{P}_{\mathrm{RG}}+\mathrm{P}_{\mathrm{ST}}+\mathrm{P}_{\mathrm{FPC}}+\mathrm{P}_{\mathrm{MI}}$

\subsubsection{Maintenance cost for the operation $\left(P_{M}\right)$}

The maintenance of solar still under operation requires following works:

- Regular filling of brackish water into solar still as input to the still.

- Removal and collection of distilled water from the collection container.

- Regular cleaning of glass cover and collector plate cover.

- Removal of salt deposited in the basin.

The maintenance cost is approximately in between 8 to $16 \%$ of the annual capital cost.

\subsubsection{Salvage value of solar still}

The FRP body and the glass cover of a solar still do not contribute for its salvage value. The component made of iron, copper and aluminium can give better salvage value after the completion of life of still if cared well by anti corrosive painting.

\subsubsection{Interest rate, $\mathrm{i} \%$}

The possible interest rate for borrowing the fund for capital investment could be as follows:

- 4\%- A subsidized rate normally offered by government agencies.

- $\quad 8 \%$ - The rate offered by the government banks.
- $12-16 \%$ - From other private source.

Thus in this economic analysis four interest rate $4,8,12$, and $16 \%$ has been considered.

Table 2 Capital cost $\left(\mathrm{P}_{\mathrm{S}}\right)$, salvage value $\left(\mathrm{S}_{\mathrm{S}}\right)$ and maintenance cost $\left(\mathrm{M}_{\mathrm{S}}\right)$ of experimental double slope active solar still

\begin{tabular}{c|c|c}
\hline Sl. No & Name of component & Price in Rs \\
\hline 1 & FRP Body $\left(\mathrm{P}_{\mathrm{FRP}}\right)$ & 9990 \\
2 & Glass cover $\left(\mathrm{P}_{\mathrm{G}}\right)$ & 800 \\
3 & Rubber Gasket $\left(\mathrm{P}_{\mathrm{RG}}\right)$ & 300 \\
4 & Iron Stand $\left(\mathrm{P}_{\mathrm{ST}}\right)$ & 1200 \\
5 & Flat plate collector $\left(\mathrm{P}_{\mathrm{FPC}}\right)$ & 2000 \\
6 & Miscellaneous cost $\left(\mathrm{P}_{\mathrm{MI}}\right)$ & 1500 \\
& (a) Capital cost $\left(\mathrm{P}_{\mathrm{S}}\right)$ & 15790
\end{tabular}

(b) Salvage value of iron stand per $\mathrm{m}^{2}$ of basin area for single and double slope solar still

\begin{tabular}{l|l|l}
\hline After 30 years & After 40 years & After 50 years \\
Rs. 600 & Rs. 800 & Rs. 1000 \\
\hline
\end{tabular}

(c) Maintenance cost $\left(\mathrm{M}_{\mathrm{S}}\right)$ generally varies from $8 \%$ to 16 $\%$ of annual capital cost $\left(\mathrm{P}_{\mathrm{S}}\right)$ of solar still.

\subsection{Payback time}

The time required by any system or device to produce as much money as was required to purchase it, is known as payback time. In other words, the number of year after which initial investment become equal to the sum of cash flow is known as payback time.

If rate of interest is $i$, payback period is $n_{p}$ and the net cash flow at the end of each year is CF then,

$P_{S}=\sum_{t=1}^{n_{p}} C F \times(1+i)^{-n_{p}}$

where,

$P_{S}=C F \times F_{R C, i, n_{p}}$

where, factor $F_{R C, i, n_{p}}$ is used to take care of interest rate and is given below

$F_{R C, i, n_{p}}=\frac{(1+i)^{n} p_{-1}}{i \times(1+i)^{n} p}$

So, from Equation (7), the payback time is

$n_{p}=\frac{\ln \left[\frac{C F}{C F-P_{S} \times i}\right]}{\ln [1+i]}$

Following different cases where the payback time will differ are considered as:

\subsubsection{Case-I -If distilled water is sold at the price it is} produced.

In this case the net cash flow is equal to the uniform end of year annual cost of solar still. Thus the equation (9) changes to

$n_{p}=\frac{\ln \left[\frac{U A_{n e t}}{U A_{n e t}-P_{S} \times i}\right]}{\ln [1+i]}$

3.22 Case-II -If distilled water is sold at the market price. 
The net cash flow is calculated by multiplying the annual yield with selling price, if distilled water is sold at the market price (Rs.10 per kg).

$C F=M_{y e n} \times S_{p}$

This CF is used in equation (9) to find out the payback time in this case.

\section{Results and Discussion}

The annual yield for double slope active solar still under forced circulation mode on the basis of energy has been given in Table 3. The cost of water per $\mathrm{kg}$ has been calculated from Equations (4) from the data of annual yield and various cost incurred to fabricate solar still.

Table 3 Annual yields for double slope active solar still with water depth on the basis of energy

\begin{tabular}{c|c}
\hline $\begin{array}{c}\text { Water depth } \\
(\mathbf{m})\end{array}$ & $\begin{array}{c}\text { Annual yield on the basis of energy } \\
\text { (kg) }\end{array}$ \\
\hline 0.03 & 1337 \\
0.04 & 1253 \\
0.05 & 1176 \\
\hline
\end{tabular}

The cost of water per $\mathrm{kg}$ from double slope active solar still on the basis of energy by varying the interest rate, $i$ on capital cost, life time of solar still, n' and varying maintenance cost $8 \%, 12 \%$ and $16 \%$ has been given in Table 4. In this economic analysis interest rates have been taken as $4 \%, 8 \%, 12 \%$ and $16 \%$ whereas the life of solar still has been considered as 30, 40 and 50 years.

Table 4 Cost of water (CPL) from experimental double slope active solar still on the basis of maintenance cost

\begin{tabular}{|c|c|c|c|c|c|c|c|c|c|c|}
\hline \multirow[b]{2}{*}{$P_{s}$} & \multirow[b]{2}{*}{$\mathrm{S}_{\mathrm{s}}$} & \multirow[b]{2}{*}{$\mathrm{i}$} & \multirow[b]{2}{*}{ n } & \multirow[b]{2}{*}{$\begin{array}{c}\mathbf{M} \\
\mathbf{Y}\end{array}$} & \multicolumn{2}{|c|}{$M_{S}(8 \%)$} & \multicolumn{2}{|c|}{$M_{S}(12 \%)$} & \multicolumn{2}{|c|}{$M_{S}(16 \%)$} \\
\hline & & & & & $\underset{\mathrm{t}}{\mathbf{U} \mathbf{A}_{\mathrm{ne}}}$ & $\begin{array}{l}\text { CPL } \\
\text { (Rs) }\end{array}$ & $\begin{array}{c}\mathbf{U} \mathbf{A}_{\mathrm{ne}} \\
\mathrm{t}\end{array}$ & $\begin{array}{l}\text { CPL } \\
\text { (Rs) }\end{array}$ & $\underset{t}{\mathbf{U} \mathbf{A}_{\mathrm{ne}}}$ & $\begin{array}{l}\text { CPL } \\
\text { (Rs) }\end{array}$ \\
\hline $\begin{array}{c}157 \\
90\end{array}$ & $\begin{array}{c}60 \\
0\end{array}$ & 4 & $\begin{array}{l}3 \\
0\end{array}$ & $\begin{array}{l}13 \\
37\end{array}$ & $\begin{array}{c}975 . \\
49\end{array}$ & 0.73 & $\begin{array}{c}1012 \\
.02\end{array}$ & 0.76 & $\begin{array}{c}1048 \\
.54\end{array}$ & 0.78 \\
\hline $\begin{array}{c}157 \\
90\end{array}$ & $\begin{array}{c}80 \\
0\end{array}$ & 4 & $\begin{array}{l}4 \\
0\end{array}$ & $\begin{array}{l}13 \\
37\end{array}$ & $\begin{array}{c}853 . \\
17\end{array}$ & 0.64 & $\begin{array}{c}885 \\
08\end{array}$ & 0.66 & $\begin{array}{c}916 . \\
99\end{array}$ & 0.69 \\
\hline $\begin{array}{c}157 \\
90\end{array}$ & $\begin{array}{l}10 \\
00\end{array}$ & 4 & $\begin{array}{l}5 \\
0\end{array}$ & $\begin{array}{l}13 \\
37\end{array}$ & $\begin{array}{c}787 \\
28\end{array}$ & 0.59 & $\begin{array}{c}816 . \\
68\end{array}$ & 0.61 & $\begin{array}{c}846 . \\
08\end{array}$ & 0.63 \\
\hline $\begin{array}{c}157 \\
90\end{array}$ & $\begin{array}{c}60 \\
0\end{array}$ & 8 & $\begin{array}{l}3 \\
0\end{array}$ & $\begin{array}{l}13 \\
37\end{array}$ & $\begin{array}{c}1509 \\
.5\end{array}$ & 1.13 & $\begin{array}{c}1565 \\
.6\end{array}$ & 1.17 & $\begin{array}{c}1621 \\
.7\end{array}$ & 1.21 \\
\hline $\begin{array}{c}157 \\
90\end{array}$ & $\begin{array}{c}80 \\
0\end{array}$ & 8 & $\begin{array}{l}4 \\
0\end{array}$ & $\begin{array}{l}13 \\
37\end{array}$ & 1427 & 1.07 & $\begin{array}{c}1479 \\
.96\end{array}$ & 1.11 & $\begin{array}{c}1532 \\
.93\end{array}$ & 1.15 \\
\hline $\begin{array}{c}157 \\
90\end{array}$ & $\begin{array}{l}10 \\
00\end{array}$ & 8 & $\begin{array}{l}5 \\
0\end{array}$ & $\begin{array}{l}13 \\
37\end{array}$ & $\begin{array}{c}1392 \\
.23\end{array}$ & 1.04 & $\begin{array}{c}1443 \\
.86\end{array}$ & 1.08 & $\begin{array}{c}1495 \\
.49\end{array}$ & 1.12 \\
\hline $\begin{array}{c}157 \\
90\end{array}$ & $\begin{array}{c}60 \\
0\end{array}$ & $\begin{array}{l}1 \\
2\end{array}$ & $\begin{array}{l}3 \\
0\end{array}$ & $\begin{array}{l}13 \\
37\end{array}$ & $\begin{array}{c}2114 \\
.56\end{array}$ & 1.58 & $\begin{array}{c}2192 \\
.97\end{array}$ & 1.64 & $\begin{array}{c}2271 \\
.38\end{array}$ & 1.7 \\
\hline $\begin{array}{c}157 \\
90\end{array}$ & $\begin{array}{c}80 \\
0\end{array}$ & $\begin{array}{l}1 \\
2\end{array}$ & $\begin{array}{l}4 \\
0\end{array}$ & $\begin{array}{l}13 \\
37\end{array}$ & $\begin{array}{c}2067 \\
.57\end{array}$ & 1.55 & $\begin{array}{c}2144 \\
.19\end{array}$ & 1.6 & $\begin{array}{c}2220 \\
.8\end{array}$ & 1.66 \\
\hline $\begin{array}{c}157 \\
90\end{array}$ & $\begin{array}{l}10 \\
00\end{array}$ & $\begin{array}{l}1 \\
2\end{array}$ & $\begin{array}{l}5 \\
0\end{array}$ & $\begin{array}{l}13 \\
37\end{array}$ & $\begin{array}{c}2053 \\
.07\end{array}$ & 1.54 & $\begin{array}{c}2129 \\
.13\end{array}$ & 1.59 & $\begin{array}{c}2205 \\
.18\end{array}$ & 1.65 \\
\hline $\begin{array}{c}157 \\
90\end{array}$ & $\begin{array}{c}60 \\
0\end{array}$ & $\begin{array}{l}1 \\
6\end{array}$ & $\begin{array}{l}3 \\
0\end{array}$ & $\begin{array}{l}13 \\
37\end{array}$ & $\begin{array}{c}2759 \\
.54\end{array}$ & 2.06 & $\begin{array}{c}2861 \\
.78\end{array}$ & 2.14 & $\begin{array}{c}2964 \\
.03\end{array}$ & 2.22 \\
\hline $\begin{array}{c}157 \\
90\end{array}$ & $\begin{array}{c}80 \\
0\end{array}$ & $\begin{array}{l}1 \\
6\end{array}$ & $\begin{array}{l}4 \\
0\end{array}$ & $\begin{array}{l}13 \\
37\end{array}$ & $\begin{array}{c}2735 \\
.4\end{array}$ & 2.05 & $\begin{array}{c}2836 \\
.72\end{array}$ & 2.12 & $\begin{array}{c}2938 \\
.04\end{array}$ & 2.2 \\
\hline $\begin{array}{c}157 \\
90\end{array}$ & $\begin{array}{l}10 \\
00\end{array}$ & $\begin{array}{l}1 \\
6\end{array}$ & $\begin{array}{l}5 \\
0\end{array}$ & $\begin{array}{l}13 \\
37\end{array}$ & $\begin{array}{c}2730 \\
.05\end{array}$ & 2.04 & $\begin{array}{c}2831 \\
.17\end{array}$ & 2.12 & $\begin{array}{c}2932 \\
.28\end{array}$ & 2.19 \\
\hline
\end{tabular}

Equation (4) has been used for calculating the cost per $\mathrm{kg}$ (CPL) and the variation for the same, for a fixed life of 30 years, with respect to interest rate, has been shown in fig. 2 and table 5. It is very clear that with increase in interest rate from $4 \%$ to $16 \%$, there is an increase in cost per liter by $183 \%$, irrespective of the capital cost of solar still. Whereas increase of maintenance cost from $8 \%$ to $16 \%$, for interest rate of $4 \%$, there is an increase of $7.48 \%$ in cost per liter irrespective of the capital cost.

Table 5 Cost per liter (CPL) w.r.t. the rate of interest for different maintenance cost for fixes system life 30 years

\begin{tabular}{c|c|c|c}
\hline \multirow{2}{*}{$\begin{array}{c}\text { Interest } \\
\text { rate, } \mathbf{i}\end{array}$} & \multicolumn{3}{|c}{$\mathbf{C P L}$} \\
\cline { 2 - 4 } & $\mathbf{M}_{\mathbf{S}} \mathbf{( 8 \% )}$ & $\mathbf{M}_{\mathbf{S}} \mathbf{( 1 2 \% )}$ & $\mathbf{M}_{\mathbf{S}} \mathbf{( 1 6 \% )}$ \\
\hline 4 & 0.729477 & 0.756790955 & 0.784105 \\
8 & 1.128809 & 1.170763595 & 1.212718 \\
12 & 1.58128 & 1.63991484 & 1.69855 \\
16 & 2.063598 & 2.140058391 & 2.216519 \\
\hline
\end{tabular}

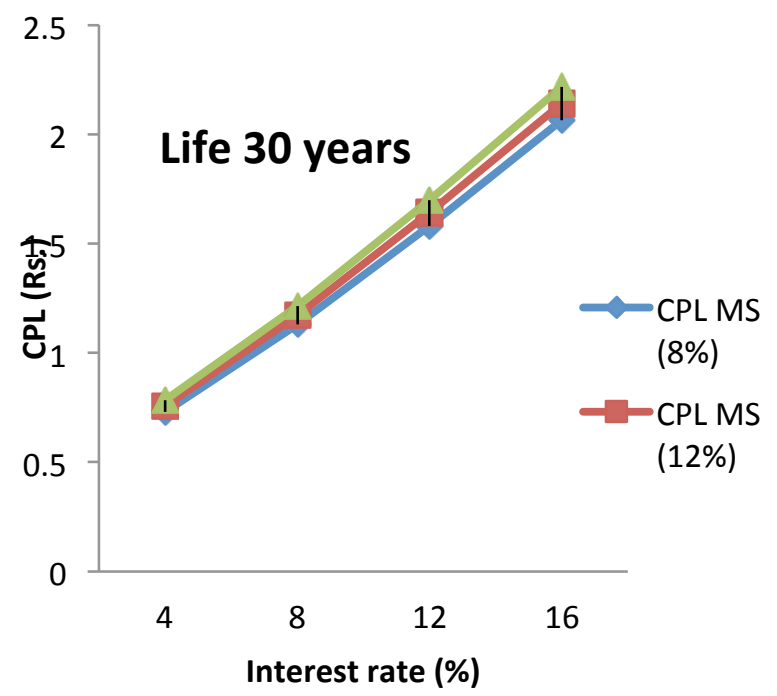

Fig.2. Variation of cost per liter (CPL) w.r.t. the rate of interest for different maintenance cost and capital cost for fixes system life 30 years

Similarly, the fig. 3 and table 6 describes the variation of cost per liter with respect to the variation in interest rate for a fixed maintenance cost of $8 \%$ and for different system life and fixed capital cost. It has been found that the cost per liter reduced by $19.29 \%$ and $2.9 \%$ if life increases from 30 years to 50 years at fixed interest rate of $4 \%$ and $12 \%$ respectively irrespective of the capital cost of solar still.

Table 6 Cost per liter (CPL) w.r.t. the rate of interest for different system life and fixed maintenance cost $8 \%$

\begin{tabular}{c|c|c|c}
\hline \multirow{2}{*}{$\begin{array}{c}\text { Interest rate, } \\
\mathbf{i}\end{array}$} & \multicolumn{3}{|c}{ CPL } \\
\cline { 2 - 4 } & $\begin{array}{c}\mathbf{n}=\mathbf{3 0} \\
\text { years }\end{array}$ & $\begin{array}{c}\text { n'= 40 } \\
\text { years }\end{array}$ & n'=50 years \\
\hline 4 & 0.729477 & 0.638004 & 0.588732 \\
8 & 1.128809 & 1.067116 & 1.041121 \\
12 & 1.58128 & 1.546142 & 1.535299 \\
16 & 2.063598 & 2.045545 & 2.041547 \\
\hline
\end{tabular}




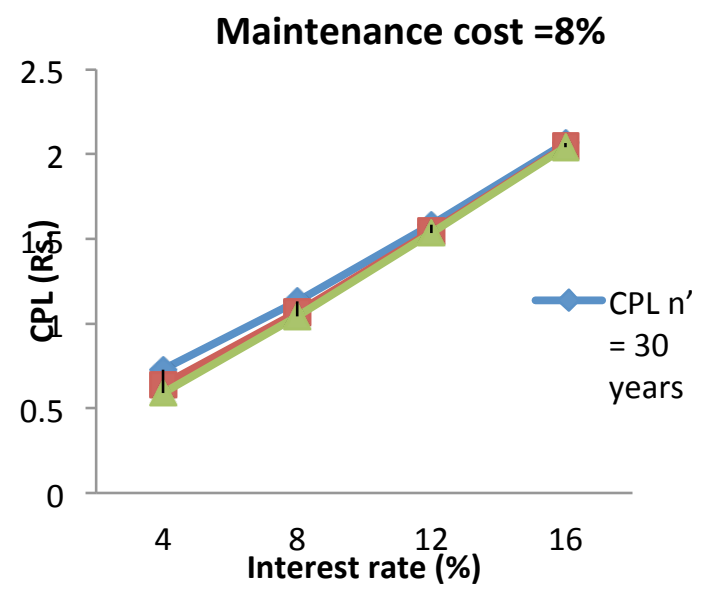

Fig.3. Variation of cost per liter (CPL) w.r.t. the rate of interest for fixed maintenance cost and capital cost for different system life

Table 7 and fig. 4 shows the variation of cost per liter with respect to the system life at fixed rate of interest for different rate of maintenance cost. It has been found that cost per liter is approximately increased by $7.48 \%$ if maintenance cost increased from $8 \%$ to $16 \%$ irrespective of the life of system and capital cost involved.

Table 7 Cost per liter (CPL) w.r.t. the system life for different maintenance cost and fixed rate of interest

\begin{tabular}{c|c|c|c}
\hline \multirow{2}{*}{ Life of solar still, $\mathbf{n}}$, & \multicolumn{3}{|c}{$\mathbf{C P L}$} \\
\cline { 2 - 4 } & $\mathbf{M}_{\mathbf{S}} \mathbf{( 8 \% )}$ & $\mathbf{M}_{\mathbf{S}} \mathbf{( 1 2 \% )}$ & $\begin{array}{c}\mathbf{M}_{\mathbf{S}} \\
\mathbf{( 1 6 \% )}\end{array}$ \\
\hline 30 & 0.73 & 0.76 & 0.78 \\
40 & 0.64 & 0.66 & 0.69 \\
50 & 0.59 & 0.61 & 0.63 \\
\hline
\end{tabular}

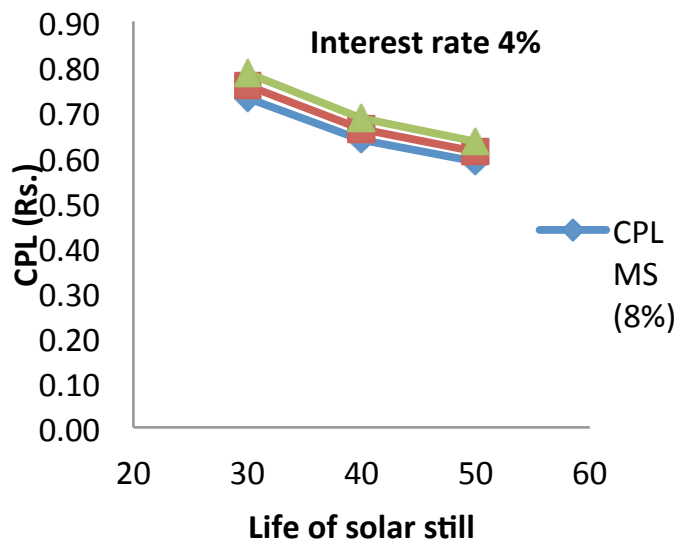

Fig.4. Variation of cost per liter (CPL) w.r.t. the system life for different maintenance cost and fixed rate of interest.

Variation of payback time for different rate of interest for two conditions of selling price i.e. at the price of production and at the market rate of Rs. 10 per $\mathrm{kg}$ have been given in Table 8 and fig.5.
Table 8 Payback time of solar still for the lifetime of 30 years with rate of interest

\begin{tabular}{|c|c|c|c|c|c|c|c|c|}
\hline $\begin{array}{l}\text { Capita } \\
1 \text { cost }\end{array}$ & \multicolumn{4}{|c|}{$\begin{array}{l}\text { Payback time }\left(n_{p}\right) \text { at the } \\
\text { price of production at } \\
\text { different interest rates }\end{array}$} & \multicolumn{4}{|c|}{$\begin{array}{l}\text { Payback time }\left(n_{p}\right) \text { at the } \\
\text { market rate }(R s .10 \text { per } \\
\text { kg) at different interest } \\
\text { rates }\end{array}$} \\
\hline $\mathrm{P}_{\mathrm{S}}$ & $\begin{array}{l}i= \\
4 \%\end{array}$ & $\begin{array}{l}i= \\
8 \%\end{array}$ & $\begin{array}{l}\mathrm{i}= \\
12 \%\end{array}$ & $\begin{array}{l}i= \\
16 \%\end{array}$ & $\begin{array}{l}i= \\
4 \%\end{array}$ & $\begin{array}{l}i= \\
8 \%\end{array}$ & $\begin{array}{l}\mathrm{i}= \\
12 \\
\%\end{array}$ & $\begin{array}{l}\mathrm{i}= \\
16 \\
\%\end{array}$ \\
\hline Rs. & year & year & year & year & $\begin{array}{l}\text { yea } \\
\mathrm{r}\end{array}$ & $\begin{array}{l}\text { yea } \\
\mathrm{r}\end{array}$ & year & year \\
\hline 15790 & $\begin{array}{l}16.6 \\
4\end{array}$ & $\begin{array}{l}19.9 \\
7\end{array}$ & $\begin{array}{l}23.5 \\
5\end{array}$ & $\begin{array}{l}26.5 \\
8\end{array}$ & $\begin{array}{l}1.2 \\
3\end{array}$ & $\begin{array}{l}1.2 \\
8\end{array}$ & $\begin{array}{l}1.3 \\
4\end{array}$ & $\begin{array}{l}1.4 \\
1 \\
\end{array}$ \\
\hline
\end{tabular}

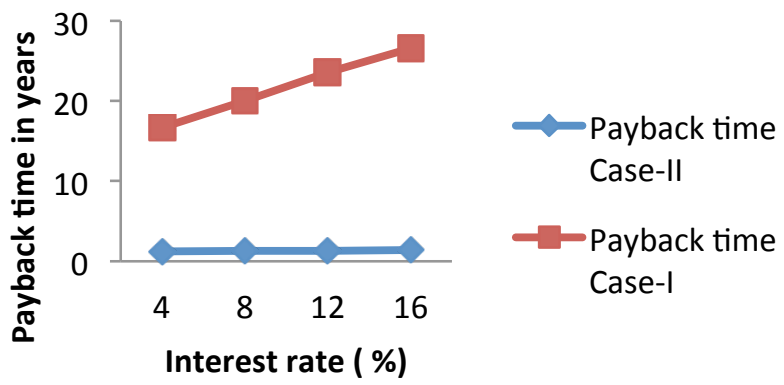

Fig.5 Variation of payback time $\left(\mathrm{n}_{\mathrm{p}}\right)$ with respect to the fixed capital cost $\left(\mathrm{P}_{\mathrm{S}}\right)$ with interest rate

\section{Conclusions}

The following are the conclusions drawn on the basis of economic analysis:

The cost of water per $\mathrm{kg}$ from experimental double slope active solar still is minimum (Rs. 0.59), when the interest rate, $i$, and the lifetime of solar still, $n$ ' is taken as $4 \%$ and 50 years respectively. The cost per $\mathrm{kg}$ is maximum (Rs. 2.22), when interest rate, $i$, and the lifetime of solar still, n' is taken as $16 \%$ and 30 years respectively.

The lowest payback time (1.23 years) is observed when the selling price of water (Rs. 10 per $\mathrm{kg}$ ), capital cost of solar still (Rs 15790) and rate of interest is $4 \%$ whereas the highest payback time (26.58 years) was found at the same capital cost and rate of interest $16 \%$ and selling price of water is equal to the price of production.

\section{Symbols}

CF Net cash flow at the end of each year (Rs.)

CPL Cost of distill water per kilogram based on energy (Rs. $/ \mathrm{kg}$ )

$\mathrm{F}_{\mathrm{CR}, \mathrm{i}, \mathrm{n}}$, Capital recovery factor

$\mathrm{F}_{\mathrm{SR}, \mathrm{i}, \mathrm{n}}$, Sinking fund factor

$\mathrm{i}$ Interest rate, $(\%)$

$\mathrm{M}_{\mathrm{S}} \quad$ Maintenance cost (Rs.)

$\mathrm{M}_{\text {yen }} \quad$ Annual yield of solar still based on thermal energy

$(\mathrm{kg})$

n' Expected life of solar still

$\mathrm{n}_{\mathrm{p}} \quad$ Payback period, (years)

$\mathrm{P}_{\mathrm{S}} \quad$ Capital Cost of solar still (Rs.)

$\mathrm{S}_{\mathrm{S}} \quad$ Salvage value (Rs.)

$\mathrm{S}_{\mathrm{p}} \quad$ Selling price of distill water $(\mathrm{Rs} / \mathrm{kg})$

$\mathrm{UA}_{\text {net }} \quad$ Uniform end of year annual cost of the active solar still (Rs.m-2 basin area) 


\section{References}

[1] Fritzmann, C., Löwenberg, J., Wintgens, T. and Melin, T. (2007). State-of-the-art of reverse osmosis desalination. Desalination, 216, pp.1-76.

[2] Mowla, D. and Karimi, G. (1995). Mathematical modelling of solar stills in Iran. Solar Energy, 55, pp.389393.

[3] Sodha, M.S., Nayak, J.K., Tiwari, G.N. and Kumar, A. (1980). Double basin solar still. J. Energy Convers., 20 (1), pp.23-32.

[4] Zaki, G.M., EI-Dali, T., EI-Shafie, M. (1983). Improved performance of solar stills, Solar energy and the Arab world, Pergamon press, 1, pp.331-335.

[5] Tiwari, G. N. and Yadav, Y. P. (1985). Comparative designs and long term performance of various designs of solar distillate. Energy Conversion and Management, 27(4), pp.327-333.

[6] Elsayed, M. M., Taha, I. S. and. Sabbagh, J. A. (1986). Design of Solar Thermal Systems. Scientific Publishing Center, King Abdulaziz University, Saudi Arabia.

[7] Kudish, A.I. and Gale, J. (1986). Solar desalination in conjunction with controlled environment agriculture in arid zone. Energy Conversion and Management, 26(2), pp.201207.

[8] Mukherjee, K. and Tiwari, G. N. (1986). Economic analyses of various designs of conventional solar stills. Energy Conversion and Management, 26(2), pp.155-157.

[9] Delyannies, E.F. (1987). Status of solar assisted desalination: A review. Desalination, 67, pp.3-19.

[10] Sinha, S., Kumar, S. and Tiwari, G. N. (1994). Active solar distillation system-an investment alternative to a solar hot water system. Energy Conversion and Management, 35(7), pp.583-588.

[11] Minasian, A. N. and Al-Karaghoul, A. A. (1995). An improved solar still: the wick-basin type. Energy Conversion and Management, 36(3), pp.213-217.

[12] Kumar, S. and Sinha, S. (1996). Transient Model and Comparative Study of Concentrator Coupled Regenerative Solar Still in Forced Circulation Mode. Energy Conversion and Management, 37, pp. 629-636.

[13] Mu“ller-Holst, H., Kessling, W., Engelhardt, M., Herve, M. and Scho"lkopf, W. (1997). Solar thermal sea-water desalination with 24-hour thermal storage. In Proceedings of ISES Solar World Congress, Taejon, Korea, Vol. 6, pp. 168176.
[14] Lawrence, S. A., Gupta, S. P. and Tiwari, G. N. (1998). Experimental validation of thermal analysis of solar still with dye. Int. J. Solar Energy, 6, 291-305.

[15] Adhikari, R.S. and Kumar, A. (1999). Cost optimization studies on a multi-stage stacked tray solar still. Desalination, 125, pp.115-121.

[16] García-Rodríguez, L., Palmero-Marrero, A.I. and Gómez-Camacho, C. (1999). Application of direct steam generation into a solar parabolic trough collector to multieffect distillation. Desalination, 125, (1-3), pp.139-145. [17] Eduardo Rubio-Cerda, E. Miguel A. Porta-Ga'ndara, Jose' L. Ferna'ndez-Zayas (2002). Technical note, Thermal performance of the condensing covers in a triangular solar still, Renewable Energy, 27, pp. 301-308.

[18] Fath, H.E.S., El-Samanoudyb, M., Fahmy, K. and Hassaboud, A. (2003). Thermal-economic analysis and comparison between pyramid-shaped and single-slope solar still configurations. Desalination, Volume 159, Issue 1, pp.69-79.

[19] Badran, O.O. and Al- Tahaineh, H.A. (2005). The effect of coupling a flat-plate collector on the solar still productivity. Desalination, 183, pp.137-142.

[20] Tiwari, A.K. and Tiwari, G.N. (2006). Effect of water depths on heat and mass transfer in a passive solar still: in summer climatic condition. Desalination, Vol. 195, pp.7894.

[21] Phadatare, M.K. and Verma, S.K. (2007). Influence of water depth on internal heat and mass transfer in a plastic solar still. Desalination, 217, pp.267-275.

[22] Ahsan, A. and Fukuhara, T. (2010). Mass and heat transfer model of tubular solar still. Solar energy, 84, pp.1147-56.

[23] Rajamanickam, M.R. and Ragupathy, A. (2012). Influence of Water Depth on Internal Heat and Mass Transfer in a double slope solar still, Energy procedia, 14, pp.1701-08.

[24] Kabeel, A.E., Khalil, A., Omara, Z.M. and Younes, M.M. (2012). Theoretical and experimental parametric study of modified stepped solar still. Desalination, 289, pp.12-20.

[25] Tenthani, C., Madhlopal, A. and Kimambo, C.Z. (2012). Improved solar still for water purification. Journal of Sustainable Energy \& Environment, 3, pp.111-113.

[26] Tiwari, G.N. (2002). Solar Energy: Fundamentals, Design, Modeling and Applications. Narosa Publishing House, New Delhi and CRC Publication, New York. 